\title{
Correction to: Balancing selection versus allele and supertype turnover in MHC class II genes in guppies
}

\section{Magdalena Herdegen-Radwan (i) - Karl P. Phillips (i) - Wieslaw Babik - Ryan S. Mohammed • Jacek Radwan (i)}

Published online: 9 February 2021

(C) The Author(s), under exclusive licence to The Genetics Society 2021

\section{Correction to: Heredity}

https://doi.org/10.1038/s41437-020-00369-7
Unfortunatley, in the first published version the acknowledgment part was incomplete. The following part was missing: "Most mtDNA sequences have been produced by SMTB2018 students".

The original article has been corrected. 